\title{
Expression of proteins Heat-Labile (Lt-1) and Heat-Stable (STa) Escherichia coli expression of proteins Heat-Labile (Lt-1) and Heat-Stable (STa) Escherichia coli
}

\author{
Alessandra Cavalcante, Maria Eliza Caldas dos Santos, Luís André Morais Mariúba, Paulo Afonso Nogueira \\ From 5th Congress of the Brazilian Biotechnology Society (SBBIOTEC) \\ Florianópolis, Brazil. 10-14 November 2013
}

\section{Introduction}

Escherichia coli has a direct relationship with the diarrheagenic diseases, which occur quite in developing countries due to poor sanitation system and public health. It mainly affects children, causing a rate of morbidity and mortality worrying.

This bacterium has a versatility of strains expressing different mechanisms and virulence factors, thus the importance in studying the taxonomy of these cepas. Classified into six categories: enteropathogenic E.coli (EPEC), enterotoxigenic E. coli (ETEC), enteroinvasive $E$. coli (EIEC), enterohemorrhagic E. coli (EHEC), enteroaggregative E. coli (EAEC) and diffusely adhering E. coli (DAEC). Among them, ETEC is the most common etiologic agent of infantile diarrhea related and has the characteristic resist peristaltic movements and adhere to the small intestine produce enterotoxin. The enterotoxins are proteins encoded by plasmids and occurring in two forms: one stable toxin (ST) which may be of the type Sta and Stb or and a labile toxin (LT), which also can be of two types LT and LT-1 or LT -2. Strains of ETEC causes diarrhea when adhere to enterocytes of the small intestine, mediated by one or more adhesins called CFA (colonization factor antigens).

The development of antisera and specific antibodies identification of species and subspecies of Enterobacteriaceae prevent the misuse of antibiotics, will enable the taxonomic study and facilitate medical diagnosis.

\section{Methods}

This study samples of enterotoxigenic E. coli (ETEC) are used the bank's sample Institute Leônidas and Maria Deane (ILMD-FIOCRUZ). After extraction of genomic DNA samples, was made the standardization of PCR. The result was visualized on 1.5\% agarose gel and bands for the purification of LT-1 and Sta genes was used QIAquick Gel Extraction Kit QIAGEN. Then, the preparation of competent cell was made with top 10 for cloning and subcloning, DH 55 pLysS and BL21 for expression. Purified fragments were ligated to the vector pGEM T Easy cloning and transformation was performed. The white colonies obtained after transformation of bacteria with binding were subjected to screening by PCR and sent for sequencing. Plasmids were digested by the restriction enzymes EcoR1 and BamH1 cloning vector and $\mathrm{pQE}$ (Invitrogen) was digested using enzymes Sph1 and Pst1. Fragments linked to expression vectors were inserted by transformation into BL21 pLys plasmid and subjected to extraction. Confirmation of the expression of target proteins was performed by SDS-PAGE and confirmation of gene expression was used Western blot (Invitrogen).

\section{Results}

Confirmation of cloning was performed by PCR with sense and antisense primer pGEM of the genes chosen allowing increasing the size of the fragment. In the subcloning, we used the restriction enzyme EcoR1 digested that the correct gene Sta, however digested LT-1 gene sequences not expected. Due to this gene for the expression of LT will use an expression plasmid (pQE) different. 
Protein expression heat-stable Sta using plasmid pRSETC was seen in Western Blot presenting highest expression pellets and size of $4 \mathrm{kDA}$.

Published: 1 October 2014

\section{References}

1. Nataro JP, Kaper JB: Diarrheagenic Escherichia coli. Clin.. Microbiol Rev 1998, 11(1):142-201.

2. Aguerro ME, Reyes L, Prado V, Orskov I, Orskov F, Cabello FC: Enterotoxigenic Escherichia coli in a population of infants with diarrhea in Chile. J Clin Microbiol 1985, 22(4):576-58.

3. Sambrook J, Fritsch EF, Maniatis T: Molecular cloning: A laboratory manual., 2 1989, 1,2 and 3.

4. Gomes TA, Rassi V, MacDonald KL, Ramos SR, Trabulsi SR, Vieira MA, Guth BE, Ivey C, Toledo MR, Blake PA: Enteropathogens associated with acute diarrheal disease in urban infants in São Paulo, Brazil. J Infect Dis 1991, 164(2):331-337

doi:10.1186/1753-6561-8-S4-P43

Cite this article as: Cavalcante et al:: Expression of proteins Heat-Labile (Lt-1) and Heat-Stable (STa) Escherichia coli expression of proteins HeatLabile (Lt-1) and Heat-Stable (STa) Escherichia coli. BMC Proceedings 2014 8(Suppl 4):P43.

\section{Submit your next manuscript to BioMed Central} and take full advantage of:

- Convenient online submission

- Thorough peer review

- No space constraints or color figure charges

- Immediate publication on acceptance

- Inclusion in PubMed, CAS, Scopus and Google Scholar

- Research which is freely available for redistribution

Submit your manuscript at www.biomedcentral.com/submit 